\title{
PENGARUH MADU TERHADAP FREKUENSI BATUK DAN NAPAS SERTA RONKHI PADA BALITA PNEUMONIA
}

\author{
Diah Ayu Agustin ${ }^{1, *}$, Nani Nurhaeni ${ }^{2}$, dan Nur Agustini ${ }^{2}$ \\ ${ }^{1}$ Akademi Keperawatan Bina Insan Jakarta, Indonesia \\ ${ }^{2}$ Program Studi Magister, Fakultas Ilmu Keperawatan, Universitas Indonesia, \\ Depok 1524, Indonesia \\ *) E-mail : diahayu@akperbinainsan.ac.id
}

Dikirim: Agustus 2016, diterbitkan: April 2017

\begin{abstract}
ABSTRAK
Balita pneumonia mengalami batuk, napas cepat, dan ronkhi. Madu memiliki efek antimikroba dan antibodi yang dapat menghambat pertumbuhan agen mikroba penyebab pneumonia. Tujuan penelitian: mengetahui pengaruh pemberian madu terhadap frekuensi batuk, frekuensi napas, dan ronkhi balita pneumonia. Metode: Desain penelitian quasi-experimental: pre-test-post-test, non-equivalent control group. Jumlah sampel 34 balita berdasarkan rumus besar sampel kategorik berpasangan. Kelompok intervensi sejumlah 17 orang, diberikan madu murni 2,5 cc 30 menit sebelum anak tidur malam ( \pm pukul 18.00) selama 3 hari. Kelompok kontrol sejumlah 17 orang diberikan air putih 2,5 cc 30 menit sebelum anak tidur malam ( \pm pukul 18.00) selama 3 hari. Pengukuran hasil penelitian dilakukan pada hari pertama sebelum perlakuan dan hari keempat setelah perlakuan. Instrumen yang digunakan ialah timer, stetoskop, lembar observasi, dan kuesioner. Analisis data bivariat berpasangan menggunakan marginal homogenity, pair t test, dan Mc Nemar. Analisis data bivariat tidak berpasangan menggunakan Kolmogorov Smirnov, Fisher exact, dan independent t test. Hasil: Hasil penelitian menemukan adanya pengaruh yang bermakna pada pemberian madu terhadap frekuensi batuk $(\mathrm{p}=0,001)$, frekuensi napas $(\mathrm{p}=0,0001)$, dan ronkhi $(\mathfrak{p}=0,012)$ antara kelompok kontrol dan kelompok intervensi. Kesimpulan: Rekomendasi penelitian ialah perlu menerapkan pemberian madu pada balita pneumonia untuk menurunkan batuk, frekuensi napas, dan ronkhi.
\end{abstract}

Kata Kunci: balita pneumonia, frekuensi batuk, frekuensi napas, madu, ronkhi.

\section{EFFECT OF HONEY ON FREQUENCY OF COUGH, RESPIRATION AND RHONCHI IN UNDER- FIVE CHILDREN WITH PNEUMONIA} ABSTRACT

Under-five children with pneumonia experience cough, rapid breathing, and rhonchi. Honey has antimicrobial and antibody effects which can inhibit the growth of pneumonia-causing microbial agents. Objective: To identify the effect of honey on frequency of cough, respiration, and rhonchi in under-five children with pneumonia. Methods: This study employed quasiexperimental research with pretest-posttest, non-equivalent control group. The number of samples of 34 under-five children based on the formula of categorical paired samples. The intervention group numbering 17 people was given $2.5 \mathrm{cc}$ of pure honey 30 minutes before the child slept at night ( \pm 06:00 pm) for 3 days. The control group numbering 17 people was given $2.5 \mathrm{cc}$ of water 30 minutes before the child slept at night $( \pm 06: 00 \mathrm{pm})$ for 3 days. The study results were measured on the first day before treatment and the fourth day after treatment. The instruments used were timer, stethoscope, observation sheet, and questionnaire. Paired bivariate data were analyzed using marginal homogeneity, pair t test, and Mc Nemar. Unpaired bivariate data were analyzed of using Kolmogorov-Smirnov, Fisher's exact, and independent t-test. Results: The study results found a significant effect of giving honey on frequency of cough $(p=0.001)$, frequency of respiration $(p=0.0001)$, and rhonchi $(p=0.012)$ between the control group and the intervention group. Conclusion: This study recommends to give honey to under-five children with pneumonia to decrease cough, frequency of respiration, and rhonchi. Keywords: under-five children with pneumonia, frequency of cough, frequency of respiration, honey, rhonchi. 


\section{LATAR BELAKANG}

Pneumonia masih menjadi satu dari lima penyebab kematian balita di dunia dengan jumlah 1 juta pada tahun 2013 (WHO, 2014). Angka kematian pneumonia balita di Indonesia $15,5 \%$, dan insiden tertinggi pneumonia balita terjadi pada umur 12-23 bulan (21,7\%o) (Kemenkes RI, 2013).

Penatalaksanaan pneumonia menggunakan manajemen terpadu balita sakit (MTBS) dengan pemberian antibiotik dan oksigen yang sesuai. Selain antibiotik, diberikan antipiretik, pelega tenggorokan, dan pereda batuk yang aman, yaitu madu dan air jeruk nipis untuk anak di atas 1 tahun. Pemberian semua jenis obat batuk yang dijual bebas tidak dianjurkan karena mengandung atropin, codein dan derivatnya atau alkohol, serta obat dekongestan oral dan nasal (AllenPatricia, 2007; Depkes RI, 2008).

Balita pneumonia mengalami gejala batuk, napas cepat, dan ronkhi (Sazawal, Black, \& Pneumonia Case Management Trials Group, 2003; Nascimento-Carvalho dan Benguigui, 2004; Shamo'on et al., 2004; Cevey et al., 2009; Chisti et al., 2009, Al-Najjar, Al-Rabaty, \& Al-Hatam, 2013). Alternatif tindakan untuk mengatasi gejala tersebut adalah pemberian madu. Madu merupakan obat pelega tenggorokan dan pereda batuk dengan bahan yang aman diberikan untuk balita pneumonia di atas usia 1 tahun (Depkes RI, 2008).

Madu lebih dipilih orangtua karena lebih efektif dan aman untuk meredakan batuk pada malam hari dan kesulitan tidur anak yang mengalami infeksi saluran napas atas daripada obat-obatan ataupun tanpa treatment (Shadkam, Mozaffari-Khosravi, \& Mozayan, 2010; Evans, Tuleu, \& Sutcliffe, 2010; Kumar, et al., 2010; Paul, 2012; Oduwule et al., 2012; Ashkin \& Mounsay, 2013).
Zat yang terkandung dalam madu bersifat antiinflamasi, antibakteri, dan antioksidan serta antibodi (Manyi-Loh, Clarke, \& Ndip, 2011; Bagde et al., 2013; Eteraf-Oskouei \& Najafi, 2013; Alvarez-Suarez, et al., 2014; Vallianou, Gounari, Skourtis, dan Panagos et al., 2014). Bakteri penyebab pneumonia yang ditemukan sensitif terhadap madu antara lain Haemophilus influenza, Klebsiella pneumonia, dan Streptococcus pneuomonia (Ajibola, Chamunorwa, \& Eelwanger, 2012).

Tujuan penelitian ini ialah menganalisis pengaruh madu terhadap frekuensi batuk, frekuensi napas, dan ronkhi pada balita pneumonia. Penelitian dilakukan di rumah sakit yang ada di Jakarta. Pemilihan rumah sakit tersebut berdasarkan studi pendahuluan, antara lain pneumonia termasuk dalam 10 besar penyakit dan jumlah pasien balita yang dirawat dengan pneumonia selama periode Januari-Desember tahun 2014 sebanyak 151 anak. Terapi yang sudah diberikan pada pasien balita pneumonia di rumah sakit tersebut ialah terapi antibiotik, inhalasi, fisioterapi dada, diet, dan obat batuk. Madu belum digunakan sebagai obat batuk. Obat batuk tersebut mengandung bahan kimia yang memiliki efek samping bagi anak.

Berdasarkan uraian tersebut, peneliti tertarik menggunakan madu sebagai alternatif obat batuk karena bersifat alami tidak mengandung bahan kimia sehingga aman bagi anak. Penggunaan madu murni pada penelitian ini didasari oleh penelitian sebelumnya yang membuktikan bahwa pemberian madu murni lebih aman dan efektif daripada obat-obatan ataupun tanpa treatment (Paul, et al., 2007, Shadkam, Mozaffari-Khosravi, \& Mozayan, 2010; Evans, Tuleu, \& Sutcliffe, 2010; Kumar et al., 2010; Paul, 2012; Oduwule et al., 2012; Ashkin \& Mounsay, 2013). 


\section{METODE}

Desain penelitian menggunakan quasi experimental: pre-test-post-test, nonequivalent control group. Jumlah sampel 34 balita (17 intervensi, 17 kontrol). Menurut rumus besar sampel kategorik berpasangan, sampel masing-masing kelompok pada penelitian ini minimal 13 responden. Jumlah responden melebihi jumlah sampel minimal.

$$
n_{2}=n_{2}=\frac{(Z \alpha+Z \beta)^{2} \pi}{\left(P_{1}-P_{2}\right)^{2}}
$$

\section{$=\underline{(1,96+1,282)^{2}} \underline{0,3}$ $(0,50)^{2}$}

$=12,61$ dibulatkan menjadi 13

Kriteria inklusi responden yaitu balita yang sedang dirawat inap, usia $1-<5$ tahun, didiagnosis pneumonia/bronkopneumonia, memperoleh terapi antibiotik, dan lama rawat minimal 5 hari. Kriteria eksklusi adalah balita dengan pneumonia berat disertai komplikasi yang membutuhkan perawatan intensif. Penelitian ini telah mendapat persetujuan dari Lembaga Kajian Etik Fakultas IImu Keperawatan Universitas Indonesia.

Data kelompok intervensi diambil terlebih dahulu pada dua minggu pertama. Setelah jumlah sampel kelompok intervensi terpenuhi, maka dilanjutkan dengan pengambilan data kelompok kontrol. Pada hari pertama sebelum pemberian madu pada kelompok intervensi atau air putih pada kelompok kontrol dilakukan pre-test ( \pm pukul 17.00). Setelah itu, kelompok intervensi diberikan madu murni sebanyak $2,5 \mathrm{cc} 30$ menit sebelum anak tidur malam ( \pm pukul 18.00) selama 3 hari, sedangkan kelompok kontrol diberikan air putih 2,5 cc 30 menit sebelum anak tidur malam ( \pm pukul 18.00). Pada hari keempat dilakukan post-test ( \pm pukul 09.00) pada kelompok intervensi dan kelompok kontrol. Instrumen pengumpul data meliputi timer, stetoskop, lembar observasi, dan kuesioner.
Uji normalitas menggunakan Saphiro-Wilk menunjukkan beberapa variabel terdistribusi normal, hanya frekuensi napas sebelum perlakuan pada kelompok kontrol $(p=0,048)$, dan frekuensi napas setelah perlakuan pada kelompok intervensi $(p=0,011)$ yang tidak terdistribusi normal.

Hasil uji homogenitas menggunakan Levene's test menunjukkan keseluruhan variabel karakteristik balita dan variabel terikat homogen $(p \geq 0,05)$ yaitu usia balita $(p=0,260)$; jenis kelamin $(p=0,167)$; status gizi $(p=1,0)$; riwayat $\mathrm{ASI}$ eksklusif $(p=0,158)$; dan status imunisasi $(p=0,060)$, frekuensi batuk ( $p=0,954)$; frekuensi napas $(p=0,061)$; ronkhi $(p=0,175)$.

Analisis bivariat dilakukan sesuai tujuan dan hipotesis penelitian. Analisis bivariat penelitian ini yang terdiri atas analisis bivariat 2 kelompok berpasangan dan 2 kelompok tidak berpasangan menggunakan statistik nonparametrik dan parametrik.

Data variabel kategorik frekuensi batuk terdiri atas 4 kategori maka dianalisis bivariat berpasangan menggunakan statistik nonparametrik marginal homogenity. Data variabel numerik frekuensi napas berdistribusi normal maka analisis bivariat berpasangan menggunakan menggunakan paired t-test. Data variabel kategorik ronkhi terdiri atas 2 kategori maka dianalisis bivariat berpasangan menggunakan statistik nonparametrik Mc Nemar.

Data variabel kategorik frekuensi batuk dianalisis bivariat tidak berpasangan antara kelompok kontrol dan kelompok intervensi menggunakan menggunakan Kolmogorov Smirnov karena tabel silang lebih dari $2 \times 2$ sel dan terdapat expected count $<5$ lebih dari $20 \%$ dan tidak mungkin melakukan penggabungan sel.

Data variabel frekuensi napas berdistribusi normal maka analisis bivariat tidak berpasangan antara kelompok kontrol 
dan kelompok intervensi menggunakan menggunakan independent t-test. Data variabel kategorik ronkhi dianalisis bivariat tidak berpasangan antara kelompok kontrol dan kelompok intervensi menggunakan menggunakan Fisher exact test karena berasal dari tabel silang $2 \times 2$ sel dan terdapat expected count $<5$ lebih dari $20 \%$.

Tabel 1 selisih frekuensi batuk, frekuensi napas, dan ronkhi sebelum dan setelah perlakuan pada kelompok kontrol dan kelompok intervensi $(n=17)$

\begin{tabular}{|c|c|c|c|c|}
\hline \multirow{2}{*}{ Variabel } & \multicolumn{2}{|c|}{ Kelompok Kontrol } & \multicolumn{2}{|c|}{ Kelompok Intervensi } \\
\hline & Hari ke-1 & Hari ke-4 & Sebelum & Setelah \\
\hline \multicolumn{5}{|l|}{ Frekuensi Batuk } \\
\hline Tidak pernah & 0 & $1(5,9 \%)$ & 0 & $10(58,8 \%)$ \\
\hline Kadang-kadang & $5(29,4 \%)$ & $4(23,5 \%)$ & $4(23,5 \% 0$ & $7(41,2 \%)$ \\
\hline Sering & $8(47,1 \%)$ & $10(58,8 \%)$ & $6(35,3 \%)$ & 0 \\
\hline Sering sekali & $4(23,5 \%)$ & $2(11,8 \%)$ & $7(41,2 \%)$ & 0 \\
\hline$p$ value & 0,083 & & 0,0001 & \\
\hline \multicolumn{5}{|l|}{ Frekuensi Napas } \\
\hline Mean & 46,4 & 41,7 & 45,9 & 33,4 \\
\hline Standar Deviasi & 3,6 & 4,1 & 2,9 & 3,5 \\
\hline Mean difference & 4,7 & & 12,4 & \\
\hline Cl 95\% & $3,9-5,5$ & & $11,2-13,7$ & \\
\hline $\mathrm{t}$ & 13 & & 21,4 & \\
\hline$p$ value & 0,0001 & & 0,0001 & \\
\hline \multicolumn{5}{|l|}{ Ronkhi } \\
\hline Tidak ada ronkhi & $5(29,4 \%)$ & $7(41,2 \%$ & $1(5,9 \%)$ & $15(88,2 \%)$ \\
\hline Ada ronkhi & $12(70,6 \%)$ & $10(58,8 \%)$ & $16(94,1 \%)$ & $2(11,8 \%)$ \\
\hline$p$ value & 0,500 & & 0,0001 & \\
\hline
\end{tabular}

\section{HASIL}

Karakteristik balita pneumonia pada penelitian ini mayoritas berusia 12-23 bulan (38\%), jenis kelamin laki-laki $(55,9 \%)$, dan status gizi normal $(97,1 \%)$. Mayoritas balita mendapatkan ASI eksklusif $(61,8 \%)$ dan balita yang mendapat imunisasi DPT dan campak $(70,6 \%)$.

Frekuensi batuk dan ronkhi sebelum dan sesudah perlakuan pada kelompok kontrol tidak menunjukkan pengaruh bermakna, frekuensi napas menunjukkan pengaruh bermakna $(p=0,001)$. Variabel terikat pada kelompok intervensi secara keseluruhan variabel frekuensi batuk, frekuensi napas, dan ronkhi menunjukkan pengaruh yang bermakna antara sebelum dan setelah perlakuan $(p=0,0001)$.
Hasil marginal homogenity test pada Tabel 1 untuk kelompok kontrol tidak menunjukkan pengaruh bermakna pada frekuensi batuk untuk pengukuran hari ke-1 dan ke-4 $(p=0,083)$, sedangkan kelompok intervensi menunjukkan pengaruh bermakna $(p=0,0001)$.

Hasil paired t-test pada Tabel 1 menunjukkan adanya pengaruh bermakna pada frekuensi napas balita pneumonia pada kelompok kontrol maupun intervensi pada pengukuran hari ke-1 dan ke-4 $(p=0,0001$; $p=0,0001)$, dapat dilihat pada Tabel 1 .

Hasil uji Mc Nemar pada Tabel 1 untuk kelompok kontrol tidak menunjukkan pengaruh madu pada ronkhi balita pneumonia pada pengukuran hari ke-1 dan hari ke-4 $(p=0,500)$. Namun, pada kelompok intervensi 
menunjukkan adanya pengaruh bermakna $(p=0,0001)$.

Tabel 2 Selisih frekuensi batuk, frekuensi napas, dan ronkhi antara kelompok kontrol dan kelompok intervensi setelah pengukuran $(n=34)$

\begin{tabular}{|c|c|c|c|}
\hline \multirow[t]{2}{*}{ Variabel } & \multicolumn{2}{|c|}{ Kelompok } & \multirow[t]{2}{*}{ p value } \\
\hline & Kontrol & Intervensi & \\
\hline Frekuensi Batuk & & & 0,0001 \\
\hline Tidak pernah & $1(5,9 \%)$ & $10(58,8 \%)$ & \\
\hline Kadang-kadang & $4(23,550$ & $7(41,2 \%)$ & \\
\hline Sering & $10(58,8 \%)$ & 0 & \\
\hline Sering sekali & $2(11,8 \%)$ & 0 & \\
\hline Frekuensi Napas & & & 0,0001 \\
\hline Mean & 41,7 & & \\
\hline \multirow[t]{2}{*}{ Mean difference } & 33,4 & & \\
\hline & 8,3 & & \\
\hline Cl $95 \%$ & $5,6-10,9$ & & \\
\hline$t$ & 3,4 & & \\
\hline Ronkhi & & & 0,012 \\
\hline Tidak ada ronkhi & $7(41,2 \%)$ & $15(88,2 \%)$ & \\
\hline Ada ronkhi & $10(58,8 \%)$ & $2(11,8 \%)$ & \\
\hline
\end{tabular}

Hasil pada Tabel 2 menunjukkan pemberian madu berpengaruh pada frekuensi batuk melalui uji Kolmogorov Smirnov, frekuensi napas menggunakan independent t-test, dan ronkhi dengan uji Fisher exact baik pada kelompok kontrol maupun intervensi $(p=0,0001 ; p=0,0001 ; p=0,004)$. Intervensi pemberian madu pada balita pneumonia berpengaruh terhadap penurunan frekuensi batuk dan frekuensi napas, serta meniadakan ronkhi.

\section{DISKUSI}

Analisis univariat menunjukkan bahwa balita pneumonia mayoritas berusia 12-23 bulan, berjenis kelamin laki-laki, status gizi normal. Mayoritas balita mendapatkan ASI eksklusif dan mendapatkan imunisasi DPT dan campak.

Karakteristik status gizi, riwayat ASI eksklusif, dan status imunisasi penelitian ini berbeda dari penelitian lain yang menjelaskan bahwa faktor risiko pneumonia balita adalah menurunnya daya tahan tubuh pada anak dengan gizi buruk, tidak mendapat
ASI ekslusif, kurangnya imunisasi, polusi udara di luar rumah maupun dalam rumah akibat penggunaan bahan bakar kayu untuk memasak, tinggal satu atap dengan jumlah anggota keluarga yang terlalu banyak dan orangtua merokok serta kurangnya pendidikan ibu (Nurhaeni, Moralejo, \& Webber, 2007; Rudan et al., 2008; Hartati, Nurhaeni, \& Gayatri, 2012).

Perbedaan hasil penelitian ini dapat disebabkan karena perilaku hidup bersih dan sehat, kepadatan penduduk serta tingginya tingkat polusi udara di Jakarta yang berasal dari asap kendaraan bermotor dan pabrik industri, jumlah responden, dan desain penelitian yang berbeda. Desain yang menggunakan eksperimen acak terkontrol atau randomized controlled trial/RCT akan menghasilkan data yang lebih akurat.

Hasil analisis bivariat menunjukkan bahwa intervensi pemberian madu pada balita pneumonia berpengaruh terhadap penurunan frekuensi batuk. Penelitian ini senada dengan beberapa penelitian yang membuktikan bahwa efek madu dapat 
menurukan skor frekuensi batuk anak yang mengalami infeksi saluran pernapasan dan penurunan skor frekuensi batuk anak lebih tinggi pada kelompok yang diberikan madu daripada kelompok kontrol. (Warren et al., 2007; Paul et al., 2007; Cohen et al., 2012).

Madu dapat meredakan batuk karena mempunyai efek menenangkan. Rasa manis madu menyebabkan refleks pengeluaran air liur meningkatkan sekresi lendir jalan napas dengan melumasi jalan napas dan menyingkirkan pemicu yang menyebabkan keringnya jalan napas pada batuk noproduktif (Eccles, 2006; Bogdanov, 2014).

Pemberian madu pada balita pneumonia juga berpengaruh terhadap penurunan frekuensi napas cepat. Madu memiliki banyak khasiat antara lain antimikroba, antiinflamasi, dan antibodi (Manyi-Loh, Clarke, \& Ndip, 2011; Bagde et al., 2013; Eteraf-Oskouei \& Najafi, 2013; Alvarez-Suarez et al., 2014). Efek antimikroba, antiinflamasi, dan antibodi madu dapat menghambat pertumbuhan agen mikroba penyebab peradangan paru sehingga ventilasi kembali normal dan frekuensi napas cepat dapat diturunkan.

Pemberian madu pada balita pneumonia berpengaruh terhadap ronkhi. Madu dapat menghilangkan ronkhi karena efek antimikroba dan antiinflamasi madu dapat menghambat perluasan radang paru yang mengakibatkan produksi mukus berkurang dan kemudian menghilang sehingga pada saat auskultasi tidak terdengar ronkhi (ManyiLoh, Clarke, \& Ndip, 2011; Bagde et al., 2013; Eteraf-Oskouei \& Najafi, 2013; AlvarezSuarez et al., 2014).

Gejala batuk, frekuensi napas, dan bunyi ronki pada balita pneumonia saat pengkajian merupakan respons organismik terhadap ancaman internal akibat invasi mikroorganisme penyebab pneumonia. Masalah keperawatan yang ada ialah bersihan jalan napas tidak efektif dan pola napas tidak efektif. Intervensi pemberian madu dilakukan untuk mengatasi masalah bersihan jalan napas tidak efektif dan memenuhi kebutuhan oksigen yang bertujuan untuk mempertahankan wholeness (keutuhan) dan mendukung adaptasi. Pemenuhan kebutuhan oksigen termasuk tindakan mencapai konservasi energi. Selain itu, tercapai pula konservasi integritas struktural karena terjadi pemulihan struktur parenkim paru yang mengalami inflamasi sehingga dampak proses hospitalisasi dapat diminimalkan. Anak menjadi lebih nyaman dan stres orang tua berkurang, akhirnya dapat tercapai konservasi integritas personal dan konservasi integritas sosial (Alligood, 2010).

Penurunan frekuensi batuk, frekuensi napas, dan menghilangnya ronkhi yang signifikan dapat mengurangi lama rawat anak sehingga lebih efektif dan efesien dari segi ekonomi. Pemberian madu dapat memberikan kontribusi pada intervensi keperawatan balita pneumonia, dan melandasi evidence based nursing practice untuk menetapkan kebijakan pemberian madu sebagai salah satu standar perawatan balita pneumonia. Hasil penelitian menginspirasi institusi pendidikan keperawatan untuk meningkatkan kurikulum pemberian madu sebagai terapi komplementer/alternatif. Keterbatasan penelitian ini data penelitian diambil pada satu rumah sakit saja.

\section{SIMPULAN}

Pemberian madu berpengaruh terhadap frekuensi batuk, frekuensi napas, dan ronkhi balita pneumonia. Rekomendasi hasil penelitian ini adalah diharapkan institusi pelayanan mempertimbangkan intervensi pemberian madu sebagai suatu kebijakan dalam memberikan asuhan keperawatan pada anak dengan masalah pernapasan. Institusi pendidikan keperawatan dan institusi pelayanan dapat bekerja sama dalam 
mengembangkan penelitian yang bersifat inovasi terkait intervensi pemberian madu. Penelitian selanjutnya tentang pengaruh madu terhadap frekuensi batuk, frekuensi napas dan ronkhi balita dengan pneumonia dengan desain RCT, serta penelitian analisis faktor yang mempengaruhi frekuensi batuk, frekuensi napas, dan ronkhi balita pneumonia.

\section{DAFTAR PUSTAKA}

Ajibola, A., Chamunorwa, J.P., \& Eelwanger, K. H. (2012). Nutraceutical values of natural honey and its contribution to human health and wealth. Nutrition \& Metabolism, 9(61): 1-12.

Allen-Patricia, L. J. (2007). Managing acute cough in children: Evidence base guidelines. Pediatric Nursing, 33(6): 515-524.

Alligood, M. R. (2010). Nursing theory: Utilization \& application (4 $4^{\text {th }}$ Edition). Philadephia: Mosby.

Al-Najjar, S. A., Al-Rabaty, A., \& Al-Hatam, I. (2013). Analysis of chest X-Ray and clinical finding in children with pneumonia. Zanco Journal of Medical Sciences, 17(2): 2-6.

Alvarez, J., Gasparrini, M., ForbesHernández, T., Mazzoni, L., Giampieri, F. (2014). The composition and biological activity of honey: A focus on manuka honey. Foods, 3(3): 420-432.

Ashkin, E. \& Mounsey, A. (2013). A spoonful of honey helps a coughing child sleep. The Journal of Family Practice, 62(3): 145-147.

Bagde, A. B., Sawant, R. S., Bingare, S. D., Sawai, R. V., \& Nikumbh, M. B. (2013). Therapeutic and nutritional values of honey [Madhu]. International Research Journal of Pharmacy, 4(3): 19-22.

Bogdanov, S. (2014). Honey in medicine: A review. Retrieved from http://www.beehexagon.net/files/file/fileE/HealthHoney
/9HoneyMedicineReview.pdf.

Cevey-Macherel, M., Galetto-Lacour, A., Gervaix, A., Siegrist, C. A., Bille, J., Bescher-Ninet, B., Kaiser, L., Krahenbuhl, J. D., Gehri, M. (2009). Etiology of Community-acquired pneumonia in hospitalized children based on WHO clinical guidelines. European Journal of Pediatrics, 168(12): 1429-1436.

Chisti, M. J., Hug, S., Das, S. K., Malek, M. A., Ahmed, T., Farugue, A. S., Salam, M. A. (2008). Predictors of severe illness in children under age five with concomitant infection with pneumonia and diarrhea at a large hospital in Dhaka, Bangladesh. Southeast Asian J Trop Med Public Health, 39(4), 719-727.

Cohen, H. A., Rozen, J., Kristal, H., Laks, Y., Berkovitch, M., Uziel, Y., Kozer, E., Pomeranz, A., Efrat, H. (2012). Effect of honey on nocturnal cough and sleep quality: A double-blind, randomized, placebo-controlled study. Pediatrics, 130(3): 465-471.

Depkes R. I. (2008). Buku bagan manajemen terpadu balita sakit (MTBS). Jakarta: Bakti Husada.

Eccles, R. (2006). Mechanisms of the placebo effect of sweet cough syrups. Respir Physiol \& Neurobiol, 152(3): 340-348.

Eteraf-Oskouei, T., \& Najafi, M. (2013). Traditional and modern uses of natural honey in human diseases: A review. Iran J Basic Med Sci, 16(6): 731-742.

Evans. H., Tuleu. C., \& Sutcliffe, A. (2010). Is honey a well-evidenced alternative overthe-counter cough medicines?. J Royal Soc Med, 103(5): 164-165.

Hartati, S., Nurhaeni, N., \& Gayatri, D. (2012). Faktor risiko terjadinya pneumonia pada anak balita. Jurnal Keperawatan Indonesia, 15(1): 13-20.

Kementerian Kesehatan R. I. (2013). Riset 
kesehatan dasar nasional. Jakarta: Badan Penelitian dan Pengembangan Kesehatan.

Kumar, R., Lorenc, A., Robinson, N., \& Blair, M. (2011). Parents' and primary healthcare practitioners' perspectives on the safety of honey and other traditional paediatric healthcare approaches. Child: Care, Health and Development, 37(5): 734-743.

Manyi-loh, C. E., Clarke, A. M., dan Ndip, R. N. (2011). An overview of honey: therapeutic properties and contribution in nutrition and human health. African Journal of Microbiology Research, 5(8): 844-852.

Nascimento-carvalho, C. M. \& Benguigui, Y. 2004. Evaluation of the degree of tachypnea for hospitalizing children with pneumonia. Indian Pediatr, 41(2): 175-179.

Nurhaeni, N., Moralejo, D., \& Webber, K. (2007). Identification of modifiable risk factors for acute respiratory infection in Indonesian children under 5 years of age. Can J of Nurs Res, 39(3): 199-201.

Oduwole, O., Meremikwu, M. M., Oyo-Ita, A., \& Udoh, E. E. (2012). Honey for acute cough in children (review). Cohcrane Database Syst Rev, 3, CD007094.

Paul, I. M. (2012). Therapeutic options for acute cough due to upper respiratory infections in children. Lung, 190(1): 4144.

Paul, I. M., Beiler, J., McMonagle, A., Shaffer, M. L., Duda, L., Berlin, C. M. Jr. (2007). Effect of honey, dextromethorphan, and no treatment on nocturnal cough and sleep quality for coughing children and their parents. Arch of Pediatr Adolesc Med, 161(12): 1140-1146.

Rudan, I., Boschi-Pinto, C., Biloglav, Z., Mulholland, K., \& Campbell, H. (2008). Epidemiology and etiology of childhood pneumonia. Bull World Health Organ, 86(5): 408-416.

Sazawal, S., Black, R., Pneumonia Case Management Trials Group. (2003). Effect of pneumonia case management on mortality in neonates, infants, and preschool children: A meta analysis of community base trials. Lancet Infect Dis, 3(9): 547-556.

Shadkam, M. N., Mozaffari-Khosravi, H., \& Mozayan, M. R. (2010). A comparison of the effect of honey, dextromethorphan, and diphenhydramine on nightly cough and sleep quality in children and their parents. J Altern and Complement Med, 16(7): 787-793.

Shamo'on, H., Hawamdah, A., Haddadin, R., \& Jmeian, S. (2004). Detection of pneumonia among children under six years by clinical. East Mediterr Health $J, 10,482-487$.

Vallianou, N. G., Gounari, P., Skourtis, A., Panagos, J., Kazazis, C. (2014). Honey and its anti-inflammatory, anti-bacterial and anti-oxidant properties. Gen Med, 2: 132

Warren, M. D., Pont, S. J., Barkin, S. L., Callahan, S. T., Caples, T. L., Carroll, K. N., Plemmons, G. S., Swan, R. R., Cooper, W. O. (2007). The effect of honey on nocturnal cough and sleep quality for children and their parents. Arch Pediatr \& Adolesc Med, 161(12): 1149-1153.

World Health Organization. (2014). Revised WHO classification and treatment of childhood pneumonia at health facilitiesevidence summaries. Retrieved from http://www.who.int/maternal_ child_adolescent/documents/childpneumonia-treatment/en/. 